\title{
An exploratory study on clothing benefits sought by breast cancer survivors
}

\author{
YoungJu Rhee and EunOk Lee ${ }^{\dagger}$ \\ Dept. of Clothing, Sungshin Women's University, Korea \\ 유방암 수술을 받은 여성의 의복추구혜택에 관한 탐색적 연구 \\ 이 영 주·이 은 옥 ${ }^{\dagger}$ \\ 성신여자대학교 의류학과
}

\begin{abstract}
The objective of this study was to take a closer look at the clothing benefits sought by breast cancer survivors in Korea. A qualitative descriptive study was conducted, using the focus group interview. Data was collected from members of online breast cancer forum. 18 participants were breast cancer survivors who had mastectomy or lumpectomy in their 30s $\sim 50$ s. The data was analyzed using content analysis in order to identify significant themes. The analysis indicated that benefits were sought after functional/comfort, health, feminity, and compensation were found. First, breast cancer survivors considered functional/comfort to be most important benefit so as to keep the body comfortable from the weather. Second, participants put the healthy body as the first priority and chose a well-being lifestyle and were likely to wear clothes made in healthy fabric, such as organic, bamboo or charcoal. Also, they preferred to look active by wearing sport brands or outdoorwear brands. Third, after the surgery, they experienced the sense of femininity loss and the sense of crisis as a woman. Single women and married women in early 30 s recognized more seriously, and they tried to recover feminity by wearing clothes with feminine details. Forth, breast cancer survivor consumers tended to shop for the psychological compensation. In summary, consumers with breast cancer surgery, unlike general healthy women, did not sought to be economic, fashion, self-expression benefits, rather they sought health, femininity, and compensation benefits. Therefore, it seems necessary to develop proper products and marketing strategy to meet the said consumer's special needs.
\end{abstract}

Keywords: breast cancer survivors(유방암 생존자), clothing benefits sought(의복추구혜택), focus group interview (초점집단면접법)

\section{Introduction}

Ministry of Health \& Welfare(2013)의 자료에 따 르면 유방암은 우리나라 여성암 중 갑상선암에 이 어 두 번째로 빈번하게 발생하는 여성암으로, 급격

\footnotetext{
Received 16 September 2014, revised 17 October 2014, accepted 20 October 2014.

† Corresponding author (irislee@sungshin.ac.kr)

This is an Open Access article distributed under the terms of the Creative Commons Attribution Non-Commercial License (http://creativecommons.org/licenses/by-nc/3.0) which permits unrestricted non-commercial use, distribution, and reproduction in any medium, provided the original work is properly cited.
} 
하게 증가하는 추세이다. 최근 조기진단과 다양한 치료방법의 개발로 유방암 생존율은 $91 \%$ 로 달하고 있다. 우리나라는 50 60대에 주로 발생하는 서구에 비해 젊은 40 대 발생률이 높은 편이며, 40 대 이하 발생빈도 역시 전체 유방암 환자의 $20 \%$ 를 차지한다 (National Cancer Information Center, 2013). 이는 오 랜 기간 만성 상태로 암과 함께 적응하면서 살아가 는 여성의 수가 늘어남을 의미하며, 암의 심리사회 적 후유증에 오랫동안 노출되게 된다(Kim, $\mathrm{Kim}, \mathrm{Yu}$, Yong, \& Song, 2003).

유방암 초기의 여성들은 유방의 일부분을 절제 하는 부분절제수술을 받지만, 유방암 환자의 절반 정도는 완전 유방절제술을 받게 된다(Korea Breast Cancer Society, 2013). 여성의 성적매력을 상징하는 유방을 부분 혹은 전체를 절제하는 수술은 여성성 을 손상하고, 신체이미지 및 자아존중감에도 부정적 인 영향을 미친다(Kim, 2010; Lee, 2007; Macmillan Cancer Support, 2013). 또한 유방암 생존자들은 절 제된 가슴으로 인해 의복을 선택하고 착용 할 때 많은 제약과 불편함이 있는 것으로 나타났다(Feather, Rucker, \& Kaiser, 1989; Gallgher, Buckmaster, O’Carroll, Kieman, \& Geraghty, 2009).

의복은 제 2 의 피부로 자신의 이미지를 표현하 고, 신체의 단점을 보완하고, 장점을 부각하고자 하 고자 하는 도구이다. 소비자는 의복을 선택하고 착 용하는 일상적인 의복행동을 통해 의미를 부여하고, 다른 사람과 또는 사회와 소통하고자 한다(Coskuner \& Sandikci, 2004). 따라서 의복은 개인의 정서적, 사회적 만족을 얻고, 자기 이미지를 표현하고, 사회 적 정체성을 표현하는데 매우 중요한 수단이라고 할 수 있다(Roach-Higgins \& Eicher, 1992). 의복추 구혜택은 소비자가 의복의 구매와 착용으로부터 얻 으려는 주관적 보상이나 기대하는 긍정적 결과(Ahn, Hwang, \& Jung, 2005)로, 초기에는 의복추구혜택을 미와 실용성의 두 차원으로 분류하였으나(Stemm, 1980), 차츰 세분화된 연구를 통해 기능성, 사회성, 상징적 혜택 등 다양한 차원으로 도출되고 사용되 고 있다(Aaker, 1991; Peter \& Olson, 1987; Shim \& Bickle, 1994).

유방암 수술을 받은 여성들에 관련된 연구는 주 로 간호, 사회복지, 심리학적 연구로 질병 경험이나,
자아존중감, 우울 등의 심리적 상태와 삶의 질과의 상관관계 등을 규명한 연구들을 찾아볼 수 있다 (Kim \& Tae, 2011; Lim, 2006; Ryu \& Yi, 2013). 그 러나 유방암 수술을 받은 여성의 의복행동에 관련 된 연구는 전절제 수술을 받은 여성들의 인조유방 착용에 관련된 연구(Jun, Choi, \& Kang, 2012; Lee $\&$ Choi, 2001)와 전절제 수술을 받은 여성의 상흔 과 의복에 관련된 연구(Feather \& Lanigan, 1987)등 을 찾아볼 수 있을 뿐, 관련 연구가 미비한 형편이 다. 따라서 신체적인 불편함과 감정적 변화를 경험 한 유방암 수술을 받은 여성에게 있어서 의복을 통 해 추구하고자 하는 혜택을 살펴보는 것은 특정 소 비자 측면의 연구로 가치가 있을 것으로 판단된다.

본 연구의 목적은 유방암 수술을 받은 여성 소비 자들의 의복추구혜택에 대한 탐색적 연구로, 연구 를 통해 특정 소비자 집단으로서의 소비자 특성을 파악하며, 관련 업계에는 실구매자에 관한 실증적 인 자료를 제공하여 의류제품 상품기획 및 마케팅 전략을 수립하는데 도움이 되고자 한다.

\section{Background}

\section{General characteristics of breast cancer} survivors

유방암은 우리나라 여성에게 발생하는 전체 암 중 두 번째를 차지하며, 전체 여성암의 $15.4 \%$ 를 차 지하며, 환자 수는 지난 1996년 3,801명에서 2010년 1 만 6,398명으로 15 년 새 약 4.3 배가 증가하고 있다 (Ministry of Health \& Welfare, 2013). 유방암 치료 는 암세포의 절제수술 및 보조적 치료를 수반하는 데, 유방 전체를 절제하는 전절제술과 일부를 절제 하는 부분절제술 등의 수술을 받게 된다(Korea Brest Cancer Society, 2013). 유방암 수술을 받은 여성들 은 신체적으로 통증, 어깨관절의 기능 제한, 악력 및 상지의 기능 저하, 림프부종 및 피로 등의 고통 을 받으며(Fairey, Courneya, Foeld, \& Mackey, 2002; Park, Cho, \& Park, 2006), 심리적으로 우울, 신체이 미지의 변형, 재발과 전이에 대한 공포 및 삶의 질 저하 등의 감정을 가지는 것으로 보고되고 있다(Jun, 1994; Kim, 2010; Lee, 2007). 이에 유방암 생존자 들의 사회 심리적 변화와 그에 따르는 적절한 치료 
와 사회적 지원을 통해 삶의 질을 향상시키고자 하 는 연구가 다각도로 진행되고 있다.

유방암 생존자의 의복에 관련된 연구는 주로 전 절제 수술을 받은 여성의 인조유방에 관련된 연구 와 유방암 생존자를 대상으로 한 질적 연구에서 묘 사된 의생활에 관련된 내용들을 찾아볼 수 있다. 전절제 수술을 한 여성의 인조유방 사용 경험에 대 한 연구를 보면 인조유방이 무겁고 불편해 외출 시 에만 착용하고, 집에서는 거의 착용을 하지 않는다 고 하였고(Jun et al., 2012), 인조유방용 브라는 선 택의 폭이 좁고, 의복을 선택할 때에도 파인 옷이나 얇은 옷을 입었을 때 브래지어가 드러나는 것에 대 하여 신경을 많이 쓰는 것으로 나타났다(Lee \& Choi, 2001). 또한 인조유방을 사용하고 있다는 것이 알 려지는 것을 조심스러워하여 운동이나 사회활동에 제약을 받고, 의복 구매 시 인조유방으로 인해 가 장 영향을 받는다고도 하였다(Gallgher et al., 2009).

한편, Goffman(1963)은 전절제 수술을 받은 여성 들은 의복을 입을 때마다 질병 흔적을 확인하고, 이 상흔을 감추고자 하는 심리적 부담을 느끼게 되며, 이러한 사회적 상흔을 인조유방과 의복으로 숨기 려고 한다고 설명했다. Feather et al.(1989)은 건강 에 대한 염려와 함께 인조유방의 피팅, 가슴의 좌 우 불균형, 의복 착장 시 가슴이 보일까에 대한 걱정 등 을 중요한 문제로 지각한다고 했으며, Chang, Hodges, and Yurchism(2013)은 암 수술을 한 여성을 포함해 신체에 장애가 있는 9명의 여성 소비자들을 대상으 로 의복에 대한 의미를 연구하였는데, 기능성, 자아 표현, 사회적 가치 표현, 자아존중감 및 승리의 상 징으로 의복을 선택하고 착용한다고 기술하였다.

이와 같이 유방암 수술을 받은 여성을 대상으로 한 의복 관련 연구는 주로 전절제 수술을 한 여성 들의 브래지어나 인조유방에 한정된 연구가 소수 진행되었을 뿐, 의복추구혜택에 관한 연구는 찾아 보기 어려운 실정이다. 이에 본 연구에서는 유방암 수술을 받은 여성 소비자의 의복추구혜택을 알아 보고자 한다.

\section{Clothing benefits sought}

소비자들은 제품을 파악할 때 속성, 혜택, 가치의 세 가지 차원으로 파악하는데, 혜택은 상품으로부
터 얻을 수 있는 편익, 즉 주관적 만족 또는 충족되 는 욕구를 의미한다(Park, 2006). 추구혜택은 소비 자들이 제품을 구매 또는 사용할 때, 원하는 주관 적 보상이나 기대하는 긍정적 결과를 의미하는 것 으로, 언제나 일정한 것이 아니며, 제품을 사용하는 상황이나 제품의 특성, 소비자 특성에 따라 달라질 수 있다(Peter \& Olson, 1987). 추구혜택은 인구통 계적 특성, 사이코 그래픽(psychographics) 특성과 함께 시장세분화를 위해 가장 많이 사용되고 있는 방법 중 하나로, 시장세분화를 통해 소비자의 욕구 를 파악하고, 소비자들의 인식을 측정하여 새로운 제품개발과 시장개척에 유용한 자료로 활용할 수 있다(Solomon \& Rabolt, 2004). 소비자 행동연구에 서 추구혜택은 기능적 혜택, 심리적 혜택, 사회적 혜택 세 가지 차원(Peter \& Olson, 1987) 또는 심리 적 혜택, 합리적 혜택의 두 가지(Aaker, 1991) 차원 으로 분류되어 설명되어진다.

의복추구혜택이란 소비자들이 의복을 구매할 때 의복 자체의 속성뿐 아니라, 의복을 통해 얻고자 하 는 효용으로 상품 평가 기준의 한 차원이다(Ahn et al., 2005). 즉, 의복을 통하여 의복 자체가 가지는 물 리적, 기능적인 속성뿐 아니라, 심리적, 정서적, 사 회적 감정과 느낌, 가치를 포함하는 혜택을 뜻한다. 의류학에서의 추구혜택에 관련된 초기 연구는 크 게 의복의 도구적 기능과 표현적 기능을 고려하여 실용성과 미의 추구로 분류하여 의복평가 기준을 분석한 연구들로 시작되었으며(Stemm, 1980), 구매 평가기준이나 구매동기 등과 동일한 것으로 간주 되어 왔다(Kim, \& Rhee, 1991). 또한 의복추구혜택 은 소비자의 특성을 파악하고, 제품 포지셔닝을 위한 시장 세분화의 기준으로 많이 사용되고 있다(Cassill \& Drake, 1987; Jenkins \& Dickey, 1976; Shim \& Bickle, 1994).

특정 소비자 집단에 따른 의복추구혜택에 관련 된 연구를 살펴보면 다음과 같다. Ryou and Lim (1998)은 20대 여성의 의복추구혜택을 표현적 즐거 움, 개성추구, 상표가치, 어울림, 사회인정 등의 심 리적 혜택과 편리성, 품질추구, 실용성, 경제성 등 의 기능적 혜택 차원으로 밝혔다. Hwang(2003)은 남녀 대학생을 대상으로 한 연구에서 인상 향상, 유행, 개성, 체형 보완, 편안함 등으로 의복추구혜 
택을 도출하였고, Lee(2010)는 20 30대 직장여성들 은 개성, 사회인정, 유명상표, 실용성, 가격추구와 같은 혜택을 선호한다고 하였다. 주부들은 자아표현/ 개성, 브랜드가치, 가격, 품위/무난함, 품질 등을 추 구하는 것으로 나타났으며(Koh, Nam, \& Cho, 2002), 중년층 여성은 편안함, 이상적 체형, 유행, 기능성 및 경제성을 매우 민감하고 중요하게 여기고 있음 을 알 수 있었다(Lee, \& Park, 2013). 이와 같은 선 행연구를 종합하여 볼 때 의복추구혜택은 대체로 실용성이나 경제성, 품질 등과 같은 기능성 차원과 인상 향상, 체형 보완 등의 심미성 차원 그리고 자 아표현, 개성, 브랜드, 사회적 인정 등과 같은 심리 적 차원으로 나타나는 것을 알 수 있다.

\section{Research Methods}

\section{Research design}

본 연구는 유방암 수술을 받은 여성 소비자의 의 복추구혜택에 관한 탐색적 연구로, 질적 연구로 진 행되었다. 질적 연구는 사람들이 자신들의 경험, 태 도, 행동을 설명할 때 그 실제 의미는 무엇인가를 파악하려는 정확도에 중점을 두는 것으로서, 어떤 현상을 관찰하고, 가설을 세우는 귀납적인 추론을 하는 연구방법이다(Creswell, 2003). 특히, 유방암 수 술을 받은 여성들에 대한 의복 관련 연구가 부족하 다는 점을 고려할 때, 앞으로 연구의 기틀을 마련하 기 위해 질적 연구 방법 중 초점집단면접(focus group interview)을 실시하였다. 한편, 질적 연구 기법 중 의 하나인 초점 집단은 약 5 명에서 10 명 정도의 구 성원을 대상으로 특정한 문제를 이해하기 위해 구 성원 간 토론으로 이루어지는 연구방법이다. 본 연 구는 의복추구혜택이라는 특정 주제에 초점을 두 면서 참석자들의 상호작용을 통해 유방암 생존자 들의 경험과 신념을 확인한 후, 그 결과를 구조화 한다는 점에서 초점집단면접은 본 연구에 적합한 연구 방법이라고 할 수 있다.

\section{Participants}

본 연구의 대상자는 서울 및 경기 지역에 거주하 는 유방암 진단을 받고 유방절제술을 받은 여성으 로, 수술과 항암치료가 끝나 일상생활을 영위하는
30 50대 여성으로 하였다. 30 50대 여성으로 대상 을 선정한 이유는 국내 유방암 발병률이 40 대가 가 장 높고 50 대, 30 대의 순인 통계자료를 근거로 하 였다(Korea Breast Cancer Society, 2013). 대상자 모 집을 위하여 $\mathrm{D}$ 포털 사이트의 유방암 관련 커뮤니 티 가운데 가장 회원 수가 많은 $\mathrm{S}$ 카페에 연구 관 련 글을 게시하여 대상자를 모집하였다. 또한 확정 된 면접 대상자에게 지인을 제안 받는 눈덩이 표집 (snowball sampling)을 병행하여 총 18명이 모집되 었다.

연구대상자의 통계적 특성을 살펴보면 연령은 $30 \sim 58$ 세로 평균연령은 42 세이며, 30 대가 8 명, 40 대 가 7명, 그리고 50대가 3명이었다. 대상자의 교육수 준은 모두 대졸 이상이었으며, 직업은 전업주부가 10 명이었고, 직장여성은 8 명으로 나타났다. 또한 대상자는 기혼이 16 명이었고, 기혼여성 중 3 명은 자녀가 없다고 응답하였다. 본 연구 대상자 중, 유 방암 0 2기 진단을 받은 여성은 13 명이었으며, 3 기 진단을 받은 여성은 5 명이었다. 대상자의 절반 이

$\langle$ Table 1〉 General characteristics of participants

$(\mathrm{N}=18)$

\begin{tabular}{|c|c|c|c|}
\hline Characteristics & Categories & $\mathrm{N}$ & $\%$ \\
\hline \multirow{3}{*}{ Age(year) } & $30 \sim 39$ & 8 & 44.4 \\
\hline & $40 \sim 49$ & 7 & 38.9 \\
\hline & $50 \sim 59$ & 3 & 16.7 \\
\hline \multirow{3}{*}{ Marriage } & Married & 16 & 88.9 \\
\hline & Others(divorced) & 1 & 5.6 \\
\hline & Unmarried & 1 & 5.6 \\
\hline \multirow{2}{*}{ Education } & College & 15 & 83.3 \\
\hline & Graduate school & 3 & 16.7 \\
\hline \multirow{2}{*}{ Job status } & No & 10 & 55.6 \\
\hline & Yes & 8 & 44.4 \\
\hline \multirow{4}{*}{$\begin{array}{l}\text { Stage of } \\
\text { cancer }\end{array}$} & 0 & 1 & 5.6 \\
\hline & 1 & 6 & 33.3 \\
\hline & 2 & 6 & 33.3 \\
\hline & 3 & 5 & 27.8 \\
\hline \multirow{3}{*}{$\begin{array}{l}\text { Type of } \\
\text { surgery }\end{array}$} & Lumpectomy & 10 & 55.6 \\
\hline & Mastectomy & 5 & 27.8 \\
\hline & Mastectomy \& reconstruction & 3 & 16.7 \\
\hline
\end{tabular}


상인 10 명이 부분절제수술을, 5 명은 전절제수술을, 그리고 3 명은 전절제 및 복원수술을 받은 것으로 나타났다. 유방암 진단을 받은 후 경과된 기간은 약 1년부터 4년까지로 나타났다(Table 1).

\section{Data collection}

본 연구의 자료 수집은 2013년 12월부터 2014년 1 월 사이에 실시되었다. 18 명의 대상자들에게 연구 자가 직접 전화를 하여 약속시간을 정하였고, 장소 는 대상자들의 집과 가까운 커피숍의 독립된 공간 에서 진행하였다. 각 집단에는 약 4 명에서 5 명의 구성원으로 4 개의 집단이 구성되었으며, 집단별 한 번씩 면접이 진행되었고, 소요시간은 대략 120 분에 서 150 분 정도였다.

각 집단의 면접을 시작하기 전에 연구 참여자에 게 본 연구의 목적과 취지를 설명하였으며, 참여자 의 익명성 보장과 연구목적 외에는 사용하지 않을 것, 그리고 참여자가 원하면 중도에 인터뷰를 철회 할 수 있음을 설명하였다. Patton(1990)의 면접 지 침법을 따라 정해진 순서에 따라 동일한 형태로 질 문하였다. 질문은 Spradley(1980)의 발전식 연구순 서(development research sequence)를 따라 일반적 질문에서 구체적 질문의 순으로 진행하였는데, 준 비단계로 간단한 대화로 편안한 분위기를 만들고, 유방암 수술 및 의복에 관련된 내용들을 나누며 진 행하였다. 질문은 '유방암 수술 후 의복을 선택하 고 구매에 관련된 경험을 자유스럽게 말씀해 주시 기 바랍니다.'로 시작하였고, 진행과정에서 '의복을 선택할 때 가장 우선적으로 고려하는 것은 무엇인 지', ‘의복을 구매할 때 어떤 것을 가장 중요시 여 기는지', ‘수술 전과 비교하여 의복선택이나 구매 시 달라진 점이 있는지' 등에 대하여 이야기하도록 하였다. 참여자들 모두가 골고루 자신의 경험과 견 해를 나눌 수 있도록 기회를 부여하도록 하였으며, 면담 종료 전에는 '지금까지 말씀해 주신 내용 외 에 의복에 관련하여 더 하고 싶으신 말씀은 없으신 지요?'라는 마무리 질문을 하여 충분한 자료를 수 집할 수 있도록 노력하였다. 그리고 참여자가 말한 내용 중 이해되지 않거나 명확하지 않은 부분은 추 가로 질문하여 자세히 설명되도록 요청하였다. 면 접 종료 후 인적사항 기록양식을 준비하여 면접대
상자가 기록하게 하였으며, 참여에 대한 보상으로 소정의 선물을 제공하였다. 초점집단면접을 통해 다루어진 모든 내용은 참여자들의 동의하에 녹음 되었고, 녹음된 자료는 분석을 위해 필사하여 자료 의 신뢰성을 확보하고자 하였다.

\section{Data analysis}

자료의 정리와 분석을 위해서 요약, 전개, 작업기 록, 분석 및 해석의 4 가지 조사자료(Spradley, 1980) 를 모두 사용하여 정리하였다. 면접상황에서 면접 대상자가 사용하는 용어나 다음 질문을 위해 생각 나는 점들을 요약하고, 녹음된 인터뷰 내용을 모두 필사하여 작성한 전개자료, 전체 자료수집 기간 중 면접에서 느낀 점들을 기록한 작업기록, 모든 자료 들을 분석하고 해석하는 과정을 되풀이 하여 연구 결과를 제시하였다. 또한 분석과 해석의 신뢰성을 확보하고자 유방암 전문 간호사 1 인과 의류학 전문 가 2 인과 함께 도출된 결과를 공유하고, 의견을 나 눔으로써 타당성을 확립하고자 하였고, 분석과 해 석의 타당성을 확립하기 위하여 연구 참여자가 실 제로 한 말을 그대로 기술하였다. 분석 작업 이후, 본 자료 속으로 되돌아가 재분석을 통해 타당도를 높이고자 하였다.

\section{Results and Discussion}

본 연구는 초점집단면접 내용을 분석한 결과, 유 방암 수술을 받은 여성들의 의복추구혜택에 대하 여 기능/편안성, 건강성, 여성성과 보상심리성의 4 개 의 주제로 도출되었다.

\section{The clothing benefits sought of functional/ comfort}

대부분의 참여자들은 의복을 선택하고 구매할 때 의복의 기능성에 대하여 중요시 여기고 있었다. 편안한 착용감과 추운 날씨로부터 신체를 보호해 줄 수 있는 보온성, 의복의 경량성 및 투습방풍 등 의 기능을 필요로 하였다.

"옷을 살 때, 기능성을 좀 더 신경 쓰게 되었어 요. 따뜻한지, 가벼운지, 바람은 잘 막아주는지 점 
원에게 물어보고 살펴보죠. 그렇지 않아도 몸도 힘 든데, 따뜻한 옷이라고 입은 게 무거우니까 얼마나 어깨가 아프던지……그래서 따뜻하고 가벼운 구 스다운 하나 샀어요." (사례 3)

"며칠 전에 여기 카페 회원들이랑 정기모임으로 산에 갔었는데, 바람 부니까 바람이 막 들어와서 진짜 춥더라고요. 같이 간 언니들 보니까 기능성 제대로 된 옷 한 벌 사야 되겠다는 생각이 들었어 요." (사례 1)

또한, 더운 날씨에는 신체를 쾌적하게 유지할 수 있는 흡습속건 기능성 등을 우선적으로 고려하는 것으로 나타났다.

“수술 후 호르몬 약을 먹잖아요, 그 부작용으로 땀이 수시로 나고 그러더라고요. 계속 옷을 갈아입 을 수도 없고 하니까 땀 흡수가 잘 되는 소재인지 살펴보게 되죠. 그런데 면제품을 입으니까 땀 흡수 는 좋은데 마르면서 약간 한기가 느껴지는 거예요. 땀이 빨리 마르는 기능 있는 소재(흡습속건), 그걸 입으니까 좋더라고요." (사례 8)

특히 패션성, 유행성, 개성을 중요시 여기던 소 비자들도 수술 후에는 편안한 착용감을 중요시 여 기는 것으로 나타났다.

"수술 후 치료하느라 오랫동안 병원을 다니다보 니 여러 가지로 생각의 변화도 있고, 뮐 사게 되던 전과는 좀 달라진 것 같아요. 날씨가 추운데, 누가 어떻게 보던 신경 쓰는 것보다 내가 편안하게 입고 가는 게 중요해요. 원래 전에는 잘 꾸미고 다니고 집 밖에 화장 안하고는 나간 적도 없었는데, 이젠 무조건 운동화에, 두꺼운 옷 입고, 스카프에 노스페 이스 다운자켓 입고 다니게 되더라고요. 비싸서 아 들만 사 짔었는데, 수술하고 나서 하나 샀어요. 근 데 진짜 진짜 따뜻하고 좋더라고요." (사례 6)

“저는 전절제 수술을 해서 가슴이 없어요. 인조 유방도 무겁고 덥고 거추장스럽고 해서 안하고 다 니고 그랬더니 허리가 휘었다고 하더라고요. 근데
뮈 이제 이 나이에 뭐 그냥 옷으로 잘 가려 입는 거 고 예쁘고 뮈고 다 필요 없고 편하고 따스한 게 최 고죠. 전에 입던 옷 중에도 불편한 건 신발이고 옷 이고 안 입게 되서 다 남 줘 버렸어요." (사례 5)

유방암 수술 시 전이 여부를 검사하기 위해 겨드 랑이에 2 3센티의 절개를 하게 되어 수 개월간 팔 의 움직임과 활동성을 제약 받게 되고, 림프절 절 제술을 받은 여성들은 불편함이 오랫동안 지속되 기도 한다(Macmillan Cancer Support, 2013). 이로 인해 많은 참여자들은 의복의 착탈용이성을 중요 하게 여기는 것으로 나타났다.

"수술하고 퇴원해서 옷을 입으려는데 팔을 움직 일 수 없으니 옷을 입을 수가 없더라고. 무슨 옷이 이렇게 다 불편하게 생겼는지….. 그래서 잘 늘어 나고 입고 벗기 편한 옷들 시장에서 급한 대로 사 서 입고 그랬어요." (사례 4)

“림프절까지 모두 절제수술했거든, 그래서 팔에 부종 조심하라고 해서 팔을 거의 안 움직였더니 한 두 달 지나면서 팔이 올라가질 않아서 깜짝 놀랐어 요. 방사선 치료 시작해야 하는데 치료도 연기하고, 그러다보니 불편한 게 이만저만이 아니더라고요. 보통 입던 옷들이 다 뒤트임이고, 앞트임인 옷은 불편한 블라우스밖에 없고 하니까 참 입을 옷이 없 더라. 맨날 통이 넓은 티셔츠만 찾아서 입었다니 까:" (사례 7)

이상에서처럼 유방암 수술을 받은 여성들은 의 복의 기능성, 편안성, 착탈용이성 등을 중요시 여기 는 것으로 나타났다.

\section{The clothing benefits sought of health}

유방암 수술을 받은 여성들은 삶의 기준과 가치 에 있어서 건강을 가장 중요하게 여기고, 웰빙 음식 및 웰빙 라이프스타일을 추구하는데(Lim et al., 2011), 본 연구 대상자들도 의복을 통해 건강하게 보이기 원하는 욕구를 가지고 있음을 확인하였다.

"아프다는 걸 뭐 동네방네 다 이야기하는 건 아 
니니까, 외출할 때 행여 누가 아픈 사람으로 보일 까봐 얼마나 신경이 쓰이는지, 하다못해 보험사에 보험금 청구하러 갈 때도 좀 건강해 보이게 입고 가게 되요." (사례 4)

"항암할 때 머리가 없으니, 비니나 모자 쓰고 다 녔는데, 동네 엄마들 사이에서 소문나니 좀 싫더라 고요. 그래서 낮에 나갈 때는 너무 아픈 사람처럼 보이지 않고 좀 화사해 보이는 그런 옷을 입고 나 가고 그랬어요." (사례 3)

특히 젊은 소비자들은 스포츠 브랜드들의 성격 인 건강하고 활발한 이미지를 선호하며, 그 의복을 구매하고 착용함으로 브랜드 동일시로 인해 건강 한 느낌을 경험하며, 유명 브랜드로 인한 사회적 명성도 누리는 소비자도 발견할 수 있었다.

"나이키, 리복 이런데서 요가복, 운동복 사니까 더 건강해지는 거 같고 그 옷을 입으니까 갑자기 마 라톤도 띨 수 있을 거 같고 좋더라고요." (사례 2)

"운동하느라 요가도 하고, 산에도 가고 그러는 데 브랜드 없는 옷을 입고 갔을 때랑 유명 브랜드 옷을 입고 갔을 때랑, 느낌이 틀려요. 좀 더 건강해 지는 거 같고 더 자신감도 생기는 것 같고, 하여튼 좋아요." (사례 15)

또한 참여자들 가운데 유기농이나 친환경 식재 료를 구매할 뿐 아니라, 의복을 선택함에 있어서도 건강에 좋은 소재인지 살펴보고, 또한 적극적으로 구매할 의사가 있는 소비자들도 있었다.

"이젠 뮐 사도 건강에 좋은가 살펴보고 사게 되죠 $T V$ 에서 뭐가 유방암에 좋다 하면 그거 바로 사서 먹 고 친환경 농산물 사고 옷도 건강에 좋다고 붙어 있 으면 뮌지 물어보고 자세히 살펴보고 그러게 되더라 고요 대나무로 만들었다는 양말, 숯 성분이 들어간 내의도 사 봤고 또 유기농 면 티셔츠도 팔던데, 그게 더 건강에 좋은가 해서 사 보기도 했어요 (사례 4)

\section{The clothing benefits sought of feminity}

유방암 수술을 받은 여성들은 여성의 상징인 가 슴을 수술하여 여성성을 상실하게 되어 심리적 스 트레스와 정서적 불안을 경험하게 된다(Kim \& Tae, 2011; Ryu \& Yi, 2013; Yalom, 1997). 참여자들은 대부분 여성성 상실에 대한 감정은 공통적으로 경 험하고 있었으나, 특히 미혼과 30 대 초반의 젊은 여성들에게 중요한 삶의 문제로 여겨지며, 이로 인 한 기분전환이나 여성성 회복을 위한 적극적 의복 행동을 하는 것을 찾아볼 수 있었다.

"수술도 수술이지만, 치료하면서 30 대에 갱년기 증상이 오니 참 우울하더라고요. 여자가 아닌 것 같더라고요. 그래서 옷을 살 때 생전 안 사던 프릴 달리고 리본 달린 옷도 사고 샬랄라한 옷도 사고 그랬어요" (사례 2, 13)

"백화점 가면 이상하게 화려한 속옷 사고, 막 더 화려한 옷을 사게 되요. 저는 수술하고 동시 복원 수술을 했는데, 안젤리나 졸리처럼 유전적 위험이 있다고 해서 멀쩡한 쪽도 예방적 수술했거든요. 그 래서 사실 전보다 가슴이 더 크고 예뻐졌어요. 그 래서 옷 사고 그럴 때 더 예뻐 보이고 자신감도 생 기는 거 같아요. 그래도 육체적으로야 더 예뻐졌지 만, 정신적인 스트레스는 아무래도 무시하긴 어렵 죠……" (사례 11)

"저는 더 화려하게 입게 되요. 원래 뷰티쪽 관련 된 일을 했으니까, 네일케어도 하고, 머리도 화려하 게 하고 했었는데, 서른 살도 안 되어서 수술하고 하니까 약간 우울증처럼 힘들었어요. 친구들 만나 고 나면 더 힘들고, 그래서 항암하고 다닐 때도 화 려하게 입고, 가발도 패션가발로 몇 개씩 사서 바 뀌 쓰고 다니고...... 지금도 가발같이 안보이죠?" (사례 12)

이상에서처럼, 유방암 수술을 받은 젊은 여성들 은 상실된 여성성과 자아정체감을 회복하기 위하 여 의복을 선택하고 구매하는 행동을 하는 것으로 나타났다. 여성성 추구혜택은 최근 선행연구에서는 잘 나타나지 않던 것인데, 본 연구의 대상자들은 성적매력의 상징이며, 여성의 정체성을 상징하는 
유방의 절제로 인해 이를 회복하려는 욕구를 충족 시키려 하는 것으로 해석할 수 있다.

\section{The clothing benefits sought of compensation}

참여자들 대부분은 공통적으로 큰 수술을 하고, 치료를 받는 힘든 과정을 겪은 자신에 대한 보상과 격려로 쇼핑을 하기도 하고, 전에는 구매하지 않았 던 고가의 의류도 구입하기도 한다고 하였다. 이는 신체에 대한 만족도가 낮은 사람일수록 자아존중감 이나 공허함을 보상해 주려는 동기로 인해 보상소 비행동을 하게 되며, 사회적으로 인정받는 제품을 소 유한다고 한 Mason(1984)과 Wicklund and Golliwizer (1982)의 연구내용과 같은 맥락으로 이해할 수 있다.

"미래를 위해 현실을 희생하고 포기하는 것이 아닌 것 같아. 그 미래가 나한테 올지 안 올지 모르 는데, 지금 사는 동안 나는 매일이 새로운 삶이고, 예상치 않은 일이 생기니까. 사고 싶은 게 있으면 참고 안 사고 그랬는데, 이제는 과감하게 구매하는 편이에요." (사례 4, 7)

"맨날 애 보고 하느라 정신없고 대충 아무거나 우중충한 옷만 입었는데, 이젠 산에도 많이 다니고 운동도 하려고 보니까 좀 좋은 옷을 사게 됐어요. 나를 위해 투자하는 것에 인색했었는데. 비싸더라 도 전에는 안 사던 옷을 사게 되요." (사례 1, 2)

“저는 은행원이었어요. 그래서 되게 절약하고 아껴 쓰고 그랬는데, 이젠 궁상맞게 살긴 싫은거에 요. 세일하는 옷만 골라 사 입었는데, 이제 옷도 좀 사야겠어요. 병원 정기검사하고 이상 없다고 듣는 날, 바로 쇼핑하고 옷 사러 갔어요. 나를 위한 선물 로. 참 고생하고 잘 견뎠다. 내가 참 대견하더라고 요." (사례 8)

“엊그제 백화점 갔었는데, 보통은 아이 옷, 남편 옷만 들여다보고 했는데, 등산, 아웃도어 제품 파는 층에 가서 보다가 수십만 원 되는 봄 잠바 하나 샀 어요. 백화점에서 정가 주고 제 옷을 처음 산 거 같 아요. 뭐 내가 히말라야 가는 것도 아닌데, 무슨 그 렇게 비싼 기능성 잠바를 사냐 싶었는데, 그 정도
는 받을 만한 것 같아요. 너무 내가 수고했으니까:" (사례 14)

이상과 같이 보상심리성은 선행연구에서 거의 발견되지 않던 추구혜택으로 유방암 수술을 받은 소비자들은 수술과 치료과정으로 지친 심신의 위 로와 만족을 위해 다소 비싼 의복을 선택하기도 하 고, 자신을 위한 선물로 구매함으로 심리적 보상을 받기 원하는 것을 발견하였다.

\section{Conclusion}

본 연구는 유방암 생존자가 급증하는 시점에서 유방암 수술을 받은 여성 소비자들의 의복추구혜 택에 관한 탐색적 연구로 진행되었다. 질적 연구를 통해 유방암 생존자의 의복행동에 대하여 보다 현 실적으로 접근함으로 소비자 특성을 분석하고자 하 였다. 본 연구결과를 요약하면 다음과 같다.

의복추구혜택은 기능/편안성, 건강성, 여성성과 보상심리성의 4 개의 주제로 도출되었다.

첫째, 유방암 수술을 받은 여성소비자들은 의복 을 선택하고 구매함에 있어 신체를 보호하는 의복 의 기능적 측면을 가장 우선적으로 고려하는 것으 로 나타났다. 특히 보온성, 흡습속건, 경량성 등의 기능성, 편안한 착용감 및 착탈용이성을 중요시 여 기는 것을 알 수 있었다. 둘째, 의복을 통해 건강해 지고 싶은 욕구를 충족하기 위해 활발하고 화사한 색상의 의복을 선택하고, 스포츠 브랜드 의복을 구 매함으로 액티브한 브랜드 이미지와 성격을 자신과 동일시하는 경향을 보였다. 또한, 친환경소재 및 유 기농 소재 제품에 관심이 많아, 적극적인 구매행동 을 보이기도 하는 것을 발견하였다. 셋째, 유방의 일부 또는 전체를 절제하는 수술을 받은 여성 소비 자들은 손상 받은 여성성을 의복을 통해 회복하고 자 하는 의복행동을 보였다. 특히 미혼이고 30 대 초반의 젊은 여성들은 여성성을 강조하는 속옷이 나, 여성적인 디테일과 색상의 의복을 선호하는 것 을 알 수 있었다. 넷째, 감정적, 심리적 손상에 따른 보상심리로 의복을 구입함으로 자신의 가치와 사 회적 승인을 얻고자 하는 것으로 나타났다. 종합적 으로 살펴볼 때, 유방암 수술을 받은 여성들은 일 
반여성들과는 달리 건강성, 여성성, 보상심리성을 추구하는 것으로 알 수 있었으며, 일반여성들의 연 구에서 주로 나타나는 경제성, 개성, 유행, 자아표 현등과 같은 추구혜택은 발견되지 않았다.

위와 같은 결과에 따른 시사점을 제시하면 다음 과 같다.

유방암 수술을 받은 소비자들의 일반여성과 다 른 의복추구혜택이 뚜렷하게 나타났으므로, 이들을 특정 소비자 집단으로 접근하여 필요에 맞는 의복 개발과 차별화된 마케팅 전략을 세우는 것이 필요 할 것으로 보인다. 특히 소재의 기능성을 중요시 여기므로 보온성, 흡습속건, 경량성 등의 기능을 부 각하는 제품을 개발하고, 이를 소비자들에게 효과 적으로 전달할 수 있는 홍보 전략이 필요함을 시사 한다. 또한 건강하고 액티브한 브랜드 이미지를 동 일시함으로 건강해지고자 하는 소비자의 욕구를 만족시키기 위해 브랜드의 상징성 및 마케팅 활동 을 통한 이미지 구축에도 관련업계의 지속적인 관 심이 요구된다.

본 연구의 한계점은 유방암관련 온라인 커뮤니 티에서 참여를 희망한 여성을 주 대상으로 하였기 에 교육 정도, 경제 수준, 지역 및 라이프스타일 등 이 편중된 경향이 있어 연구 결과를 유방암 생존자 의 소비자행동으로 일반화시키는데 한계가 있다. 그러나 본 연구는 유방암 수술을 받은 여성 소비자 들의 의복행동연구가 미비한 상황에서 진행된 탐 색적 연구로 후속연구의 기틀을 마련하고자 하였 다. 또한 최근 웰빙 라이프스타일의 확산과 스포츠, 아웃도어웨어의 열풍이 일반 소비자들의 건강인식 증대뿐만이 아니라, 실질적인 필요를 느끼는 암 생 존자들의 니즈가 있음을 확인한 점에서 의의를 찾 을 수 있다. 따라서 본 연구의 결과를 기반으로 향 후 후속연구에서는 다양한 연령층과 대상에게 양 적연구 및 반복연구를 통해 의복행동을 연구한다 면 특정 소비자 집단이 필요로 하는 욕구를 충족시 킴과 동시에 패션상품기획자에게 제품개발에도 실 질적인 마케팅적 시사점을 줄 것으로 기대한다.

\section{References}

Aaker, D. A.(1991). Managing brand equity. New
York: The Free Press.

Ahn, K. H., Hwang, S. J., \& Jung. C. J.(2005). Fashion marketing(3rd ed.). Seoul: Suhaksa.

Cassill, N., \& Drake, M. F.(1987). Employment orientation's influence on lifestyle and evaluative criteria for apparel. Home Economics Research Journal, 16, 23-35.

Chang, H. J., Hodges, N., \& Yurchism, J.(2013). Consumers with disabilities: a qualitative exploration of clothing selection and use among female college students. Clothing and Textiles Research Journal, $32(1), 34-48$.

Coskuner, G., \& Sandikci, O.(2004). New clothing: Meaning and practices. Advances in Consumer Research, 31, 285-290.

Creswell, J. W.(2003). Research design: qualitative, quantitative, and mixed methods approaches(2nd ed.). Thousand Oaks, CA: Sage Publications.

Fairey, A. S., Courneya, K. S., Field, C. J., \& Mackey, J. R.(2002). Physical exercise and immune system function in cancer survivors: A comprehensive review and future directions. Cancer, 94, 539-551.

Feather, B. L., \& Lanigan, C.(1987). Looking good after your mastectomy. American Journal of Nursing, 87, 1048-1049.

Feather, B. L., Rucker, M., \& Kaiser, S. B.(1989). Social concerns of post-mastectomy women: Stigmata and clothing. Home Economics Research Journal, 17, 289-299.

Gallgher, P., Buckmaster, A., O'Carroll, S., Kieman, G., \& Geraghty, J.(2009). Experiences in the provision, fitting and supply of external breast prostheses: Findings from a national survey. European Journal of Cancer Care, 18, 556-568.

Goffman, E.(1963). Stigma. Englewood Cliffs: PrenticeHall.

Hwang, J. S.(2003). The internet perceived risk segments: clothing benefits sought, internet shopping attitude, and internet purchase intention. Journal of the Korean Society of Clothing and Textiles, 27(7), 746-757. 
Jenkins, M. C., \& Dickey, L. F.(1976). Consumer types based on evaluative criteria underlying clothing decisions. Home Economics Research Journal, 4, 150-162.

Jun, E. Y., Choi, S. R., \& Kang, H. S.(2012). Experiences of the use of external breast prosthesis among breast cancer survivors in Korea. Korean Journal of Women Health Nursing, 18(1), 49-61.

Jun, M. H.(1994). An Experience of life following breast cancer surgery. Unpublished doctoral dissertation, Seoul National University, Seoul, Korea.

Kim, M. Y., \& Rhee, E. Y.(1991). A study on the theoretical framework of clothing evaluative criteria. Journal of the Korean Society of Clothing and Textiles, 15(3), 321-334.

Kim, N. C., Kim, H. S., Yu, Y. S., Yong, J. S., \& Song, M. S.(2003). Disease-related stress experienced by women with mastectomy: Q methodology. Journal of Korean Academy of Women's Health Nursing, 9, 379-389.

Kim, Y. L.(2010). The complexity of body image in post-mastectomy women and social support. Korean Journal of Social and Personality Psychology, 24, 129-147.

Kim, Y. S., \& Tae, Y. S.(2011). The influencing factors on quality of life among breast cancer survivors. Journal of Korean Oncology Nursing, 11(3), 221228.

Koh, A. R., Nam, M. W., \& Cho, Y. J.(2002). A study on apparel benefits and buying behavior according to values and lifestyles. Journal of the Korean Home Economics Association, 40(5), 119-132.

Korea Brest Cancer Society(2013). Breast cancer factors \& figures in Korea. http://www.kbcs.or.kr

Lee, K. M., \& Choi, J. S.(2001). A study on the wearing conditions of mastectomy bras and breast prosthesis. Journal of the Korean Society of clothing and Textiles, 25(4), 697-706.

Lee, M. A.(2010). Comparative study between married and unmarried women on consumption values and clothing benefits -focusing on working women in their 20's and 30's. Journal of the Korean Society of Clothing and Textiles, 34(5), 808-818.

Lee, Y. J., \& Park, M. J.(2013). The middle-aged consumer's using active wear as casual wear based on the clothing benefits. The Research Journal of the Costume Culture, 21(5), 765-779.

Lee, Y. S.(2007). Psychosocial experience in post-mastectomy women. Korean Journal of Social Welfare, 59, 99-124.

Lim, I. S.(2006). Breast cancer, damaged body and sense of femininity crisis. Journal of Korean Women's Studies, 22(4), 5-45.

Lim, J. W., Yoon, H. S., Baik, O. M., Cho, J. H., Park, S. H., \& Lee, S. W.(2011). A qualitative study of health beliefs and health behaviors among Korean breast cancer survivors. Korean Journal of Social Welfare, 63(4), 155-181.

Macmillan Cancer Support(2013). Body image and cancer. http://www.macmillan.org.uk

Mason, R.(1984). Conspicuous consumption: A literature review. European Journal of Marketing, 18(3), 26-39.

Ministry of Health \& Welfare, \& National Cancer Center (2013). The Korea Central Cancer Registry(National cancer registration \& statistics 2010). http://www. mw.go.kr

National Cancer Information Center(2013). Breast Cancer Treatment. http://www.cancer.go.kr

Park, C. S.(2006). Marketing principles(3rd ed.). Seoul: Bupmunsa.

Park, H. S., Cho, G. Y., \& Park, K. Y.(2006). The effects of a rehabilitation program on physical health, physiological indicator and quality of life in breast cancer mastectomy patients. Journal of Korean Academy of Nursing, 36, 310-320.

Patton, M. Q.(1990). Qualitative evaluation and research methods(2nd ed.). Beverly Hills, CA: Sage Publications.

Peter, J. P., \& Olson, J. C.(1987). Consumer behavior: Marketing strategy, perspectives. Homewood: Irwin. Roach-Higgins, M. E., \& Eicher, J. B.(1992). Dress and 
identity. Clothing and Textiles Research Journal, 10, 1-8.

Ryou, E. J., \& Lim, S. J.(1998). A study on consumer's value systems and clothing behavior. Journal of the Korean Society of Clothing and Textiles, 22(6), 749-756.

Ryu, Y. M., \& Yi, M. S.(2013). The factors influencing quality of life in women with breast cancer. Asian Oncology Nursing, 13(3), 121-127.

Shim, S., \& Bickle, M. C.(1994). Benefit segments of the female apparel market: Psychographics, shopping orientations and demographics. Clothing and Textiles Research Journal, 12(2), 1-12.

Solomon, M. R., \& Rabolt, N. J.(2004). Consumer behavior in fashion. NJ: Prentice Hall.

Spradley, J. P.(1980). Participant observation. Wadsworth Publishing Company.

Stemm, F. A.(1980). Clothing attitudes and evaluative criteria used by employment women differing in feminine-role orientation and work orientation: Emphasis on the single again adult. Unpublished doctoral dissertation, The Ohio State University, Ohio, USA.

Wicklund, R. A., \& Gollwitzer, P. M.(1982). Symbolic self-completion. Hillsdale, NJ: Erlbaum.

Yalom, M.(1997). A history of the breast. New York: Alfred A. Knopf. 